\title{
Region and the American Presidency: Jimmy Carter as the "Southern" President
}

\section{Jason Berggren}

Georgia Southwestern State University

\begin{abstract}
This study is about region and the politics and political style of Jimmy Carter. In 1976, the former Georgia governor broke a regional barrier to become president of the United States. He was a white southerner from the Deep South. As a candidate, he regularly identified himself as being from the South and spoke with pride about his regional connections. Although being from the South may have had some political costs, Carter did not consider it a liability. It helped him win the Democratic Party nomination and the general election. It reinforced his image as a Washington outsider. Indeed, had it not been for the near solid support from his home region in the Electoral College, he would have lost to Gerald Ford. Carter was also a southern president. He used his regional identity to establish and maintain relations with other Americans and with international leaders. He employed it in domestic and foreign policy situations, most notably in his efforts to advance Middle East peace.
\end{abstract}

Keywords: regionalism, Southern culture, “the New South”, presidential politics

"There's one region of the country, even though I am President of the whole nation, that will always be close to my heart, and that's the South."

Jimmy Carter

1 Jimmy Carter, "Remarks at the Southern Salute to the President Dinner in Atlanta, Georgia," January 20, 1978, Public Papers of the Presidents: Jimmy Carter, Book I (Washington, DC: United States Government Printing Office), 156. 
As a testament to the principles of political equality and equal opportunity, it is commonly said that any American can grow up and become president. While this may be a popular notion, it is untrue. Various communities in the United States have been effectively barred from having one of their own in the White House. It was not until 1960 that the first Roman Catholic, John Kennedy, was elected. But a Catholic has not been elected since then. It was not until 2008 that an African American, Barack Obama, was elected. It remains to be seen if another can win. To date, no woman has been elected, and only one nominated by a major party.

In 1976, Jimmy Carter broke another barrier to the presidency. It was a regional barrier that had been in place since the southern states seceded in 1861 to form the Confederate States of America, the ensuing four-year civil war, and the 1868 impeachment of a president, Tennessee's Andrew Johnson. For approximately one hundred years, white southerners faced an electoral obstacle to the highest office. ${ }^{2}$ They were occasionally nominated by a major party for vice president, but not for president during this long timespan. ${ }^{3}$

Scholars have examined race, religion, and gender as key variables in U.S. presidential studies. Region has received much less attention. ${ }^{4}$ The Carter presidency raises issues of region, presidential leadership, and the politics of identity. It provides an illustration that the United States is not immune to expressions of subnational identity, representation, and politics even at the highest levels of government. It illustrates an example of the enduring, deep-seated divisiveness of the 1861-1865 Civil War in American political life. It invites comparisons to political leaders in other democracies with a history of interregional competition and conflict.

2 Andrew Johnson (Tennessee) and Lyndon Johnson (Texas) assumed the presidency due to their predecessor's assassination than by election. Consequently, the 1964 landslide election was won by an "accidental" president. Woodrow Wilson, though a Virginia native who was raised in Georgia, was elected to the presidency from New Jersey, where he was a professor and president of Princeton and where he served as governor. The last southerners directly elected to the presidency were in the antebellum period - Zachary Taylor (Louisiana) in 1848, James Polk (Tennessee) in 1844, and Andrew Jackson (Tennessee) in 1828 and 1832.

3 For most of U.S. history, southerners were only nominated by the Democratic Party. For instance, from 1920 to 1960 , Democrats nominated a southerner for vice president six times $(1928,1932,1936,1952$, 1956, and 1960). It was not until 1980 that the Republican Party finally nominated someone representing a former Confederate state. That year, Texas resident George H.W. Bush was nominated for vice president. Eight years later, Bush was nominated for president.

4 One important work that explored regionalism and the U.S. presidency was William E. Leuchtenburg, The White House Looks South: Franklin D. Roosevelt, Harry S. Truman, Lyndon B. Johnson (Baton Rouge, LA: Louisiana State University Press, 2005). 
Differing from members of Congress who represent more parochial interests and constituencies, presidents are said to represent the national interests and the whole country is the constituency. The president sits at the pinnacle of the American political system. The president is not just the chief executive of the federal government, the commander-in-chief of the country's armed forces, and chief diplomat abroad. Rather, as the head of state, the president comes to symbolize the nation and transcend its parts. Carter in some ways challenged this.

Being president of United States did not necessarily involve any serious diminution of being southern. Carter once told a crowd of supporters in Texarkana, with Arkansas governor Bill Clinton in attendance, "I remember that it was you who put me on the road to the White House to represent the finest elements of the South and the entire region." He made clear to them in the closing days of the 1980 election, "I'm a southerner, and I'm proud of it." A little over a week later, he explained to a town hall meeting in Memphis, "Being a southerner, I'm proud of my heritage." Indeed, in the final campaign swing through his native region, the incumbent president pleaded with voters in Jackson, Mississippi, to go to the polls and "let's win a victory for the South." 5

This study documents and explores features of the "southern" president from Georgia, including his peculiar electoral path to the presidency and some of the ways Carter as president proclaimed and promoted his southern identity and how he positively utilized it. The lessons Carter drew from his region's experiences to promote peace abroad, specifically in the 19781979 Camp David peace process between Israel and Egypt, are discussed.

\section{"The South has never forgotten those very important and enduring values"}

Being from Georgia, the Deep South, Carter often noted the historic character of his bid as the first southerner elected directly to the White House since antebellum times. ${ }^{6} \mathrm{He}$ speculated that not all Americans were enthu-

5 Carter, "Remarks at a Rally with Local Residents in Texarkana," October 22, 1980, Public Papers of the Presidents: Jimmy Carter, Book III, 2418, 2420; "Remarks and Question-and-Answer Session at a Town Meeting in Memphis, Tennessee," October 31, 1980, Public Papers of the Presidents, Book III, 2587; "Remarks at a Rally with Area Residents in Jackson, Mississippi," October 31, 1980, Public Papers of the Presidents, Book III, 2603.

6 See Carter, "Interview with Larry King," CNN's Larry King Live, February 1, 2006, http://transcripts.cnn. com/TRANSCRIPTS/0602/01/lk1.02.html. 
siastic about it, believing that in some quarters, the South remained suspect. Quite aware of the stereotypes and lingering suspicion, he knew his southern origin and affiliation could "place him outside the ring of acceptable candidates."7 Notwithstanding those concerns, Carter was confident that the American people were fair and well-meaning, and his region would not prevent him from winning.

In 1976, the country was looking for a fresh face, a Washington outsider, someone who represented a clean break from the failure of Vietnam, the ignominy of Watergate, and the unpopularity of Gerald Ford's presidential pardon. Carter was a good fit. He was from small-town, rural America. He was a farmer and business owner. He possessed military service and was a graduate of the U.S. Naval Academy. He was active in his local community. He was a person of strong religious faith. He attended church regularly, taught Sunday school, and freely discussed the meaning of his faith, including how he became a "born again" believer in Jesus. This became national news and it played well not just in the "Bible Belt" South, but across the United States. For many, he was an ideal choice for the country's bicentennial year. ${ }^{8}$

Carter pledged to reintroduce morality in the White House. He aimed to lead a national renewal and a rededication to upholding the truth and common decency. He was the "redeemer" candidate who provided Americans the opportunity to absolve their collective sins from the Lyndon Johnson and Richard Nixon presidencies. In his controversial 1976 Playboy interview, Carter exclaimed, "I don't think I would ever take on the same frame of mind that Nixon or Johnson did - lying, cheating and the distorting the truth. Not taking into consideration my hope for my strength of character, I think that my religious beliefs alone would prevent that from happening to me. I have that confidence. I hope it's justified."

Carter further argued that morality should impact public policy, particularly foreign policy. He believed the United States should not only strive

7 James Wooten, Dasher: The Roots and Rising of Jimmy Carter (New York: Warner Books, 1979), 26.

8 D. Jason Berggren, “December 1974: President Carter's Improbable Run Began 40 Years Ago," Americus Times-Recorder, December 12, 2014, 1A; Berggren, " I'm a Candidate for President': Carter Announced Candidacy in Atlanta 40 Years Ago," Americus Times-Recorder, December 19, 2014, 1A, 5A.

9 Randall Balmer, God in the White House, A History: How Faith Shaped the Presidency from John F. Kennedy to George W. Bush (New York: HarperCollins Publishers, 2008), 78-107; Randall Balmer, Redeemer: The Life of Jimmy Carter (New York: Basic Books, 2014); Carter, "Interview with Robert Scheer," Playboy, November 1976, 86 . 
to be great. It should strive to be good. "We have set a different standard of ethics and morality as a nation than we have in our own private lives as individuals who comprise the nation. And that ought to be changed." The United States could yet become once more "a nation that is as good and honest, decent, truthful, and competent and compassionate and as filled with love as are the American people." 10

Perhaps, as he suggested at times, a southerner could address such matters better and more convincingly and to a greater degree than Americans from the Northeast, Midwest, or the West. He contended that southerners "have a conviction that a better life must depend on hard work, on a belief in God, on strong families, on farming the land, on giving people the chance for a job, on taking care of those who can't care for themselves. We believe in a strong nation, a nation whose military strength is second to none on Earth," and "the South has never forgotten those very important and enduring values." 11

The former Georgia governor effectively chastised and repudiated the political leadership of both major parties. This gave him an advantage over several of his rivals for the Democratic Party's presidential nomination namely those who were members of Congress. They just represented more of the same. Carter's leading challengers for the Democratic nomination included Senators Henry Jackson (Washington), Frank Church (Idaho), and Birch Bayh (Indiana), and Representative Morris Udall (Arizona). ${ }^{12}$

\section{"Each of their public handshakes to me was worth a million Yankee votes!"}

Carter had another distinct advantage. He was a "New South" politician, a symbol of a revitalized South. He was a stark contrast to the champion of the "Old South", Alabama Governor George Wallace. This was most clear on the issue of race. Unlike Wallace, who was most remembered for his

10 Carter, A Government As Good As Its People (Fayetteville, AR: University of Arkansas Press, 1996; originally published in 1977), 52, 55-56.

11 Carter, "Remarks at a Carter/Mondale Rally at Tri-City Municipal Airport, Tennessee," October 9, 1980, Public Papers of the Presidents, Book III, 2118; "Remarks to Residents in Winston-Salem, North Carolina," October 9, 1980, Public Papers of the Presidents, Book III, 2141; "Remarks at a Rally with Local Residents in Texarkana," October 22, 1980, Public Papers of the Presidents: Jimmy Carter, Book III, 2418.

12 Gerald M. Pomper, "The Nominating Contests and Conventions," in The Election of 1976: Reports and Interpretations, edited by Marlene M. Pomper (New York: David McKay Company, Inc., 1977), 7-10. 
full-throated commitment in 1963 to racial "segregation now, segregation tomorrow, and segregation forever," Carter was committed to racial integration and racial equality. ${ }^{13}$

Carter additionally favored regional economic modernization and diversification. He envisioned Atlanta becoming a player in international trade and a film industry competitor to Hollywood. As a former member and chair of the county school board, he supported improving educational conditions and investing in the public schools. Carter and his wife Rosalynn attended public schools, and so did their four children. ${ }^{14}$

For his embrace of civil rights for all, Carter earned the full support of the King family, most visibly the Rev. Martin Luther King, Sr., and Mrs. Coretta Scott King, the father and widow of the immortal civil rights leader. Three decades later, at Mrs. King's funeral, Carter identified the national significance of their support. He said, "When Coretta and Daddy King adopted me in 1976, it legitimized a southern governor as an acceptable candidate for president. Each of their public handshakes to me was worth a million Yankee votes!" The success of the civil rights movement also lifted from all southerners a "millstone around our necks". Black southerners constituted a critical part of Carter's electoral strength and remained with him even when he stumbled on race issues. ${ }^{15}$

Carter's South was ready to join the mainstream of the country. He believed that the country had changed as the South had changed. Regional

13 Russell Duncan, "A Native Son Led the Way: Jimmy Carter and the Modern New South," in The Southern State of Mind, edited by Jan Nordby Gretlund (Columbia, SC: University of South Carolina Press, 1999), 147-160; Daniel K. Williams, The Election of the Evangelical: Jimmy Carter, Gerald Ford, and the Presidential Contest of 1976 (Lawrence, KS: University of Kansas Press, 2020), 67-69.

14 Carter, Why Not The Best? (New York: Bantam Books, 1976; originally published in 1975), 140-146; In 2019, the Jimmy Carter Presidential Library and Museum opened an exhibit entitled, "Georgia on My Screen: Jimmy Carter and the Rise of the Film Industry". See Bo Emerson, "Carter Library exhibit tells story of Georgia's film industry," Atlanta Journal-Constitution, May 6, 2019, https://www.ajc.com/entertainment/attractions/carter-library-exhibit-tells-story-georgia-film-industry/wd39Vook1Uf9Ui7p4crAnK/. Amy Carter was the first presidential child to attend a D.C. public school since the early 1900s. See "Amy Carter May Go to a Public School," New York Times, July 20, 1976, 18; "White House Associations with Public Schools in the District of Columbia," The White House Historical Association, https://www.whitehousehistory.org/ associations-with-public-schools-dc.

15 Carter, "Remarks at Funeral Service for Coretta Scott King in Lithonia, Georgia," February 7, 2006, available at https://www.cartercenter.org/news/documents/doc2295.html; Carter, Why Not The Best?, 40; Berggren, "Jimmy Carter, Soul Brother," The Keynoter: Journal of the American Political Items Collectors (Fall/Winter 2004): 24-25; Berggren, "With big wins in Wis. and Pa., Carter nomination more certain," Americus Times-Recorder, June 8, 2016. 
enmity was subsiding. His South was full of ebullience and confidence, not rage and resentment. He greeted the country with a grin, not a scowl. His Florida primary win over Wallace in March 1976 signified the political rise of the "New South". His subsequent southern victories spelled the end of Wallace as the premier regional spokesperson. In June, citing the importance of having a southerner in the White House, Wallace endorsed Carter. Amazingly, with the King family and Wallace behind him, Carter forged a viable biracial coalition in his home region, and it brought him to victory. ${ }^{16}$

As the undisputed leader of the "New South", Carter judged his national prospects as bright. In Why Not the Best, he asserted, "Sectional or geographical prejudice is becoming a minimal political factor." On CBS' Face the Nation, he determined that he had not "suffered because I'm a southerner" at the ballot box. Empirical evidence showed that Carter overcame southern bias in key northern states, like New York. ${ }^{17}$

\section{"Jimmy Carter was too much to overcome"}

Carter's electoral path to victory was unusual. With 297 electoral votes, he had a majority, but not an especially strong one. His was not a national victory, it was regional-plus. In contrast to most other twentieth-century and twenty-first century Democratic presidents, Carter was the only one since Woodrow Wilson in 1916 who would have otherwise lost the general election had it not been for the South.

Watergate and the Nixon pardon were supposed to have ruined any chance for President Ford to win. However, outside of the South, he beat Carter by 49 electoral votes, 228 to 179 . In fact, had Ford carried Ohio and Wisconsin or Ohio, Hawaii, and the one electoral vote from Washington that was faithlessly cast for Ronald Reagan, he would have prevailed. This

16 Berggren, "The Battle for the South: Carter beat Wallace in Florida in 1976," Americus Times-Recorder, March 16, 2016, 1A, 5A; James T. Wooten, “Old South Bows to New As Wallace Meets Carter," New York Times, June 13, 1976, 34; “A Call at the Depot; Transcript of the Call," Plains Depot Exhibit, Jimmy Carter National Historic Site, Plains, Georgia, February 16, 2016.

17 Carter, Why Not The Best?, 160; "Interview with George Herman, Ed Rabel, and Robert Novak," CBS" Face the Nation, March 14, 1976, The Presidential Campaign 1976: Jimmy Carter (Washington, DC: United States Government Printing Office, 1978), 107; see also "Remarks at the Martin Luther King Hospital in Los Angeles, California," June 1, 1976, The Presidential Campaign 1976, 197-198; Robert M. Pierce, "Jimmy Carter and the New South: The View from New York," in Perspectives on the American South: An Annual Review of Society, Politics and Culture, Volume 2, edited by Merle Black and John Shelton Reed (New York: Gordon and Breach Science Publishers, 1984), 181-195. 
strongly suggests that the conventional Watergate explanation for understanding the 1976 election may be overstated.

In the South, defined as the eleven states that constituted the 1861 Confederacy, Carter won a regional landslide; he bested Ford by a whopping 106 electoral votes, 118 to 12 . His only loss was a narrow one in Virginia. He picked up another 43 electoral votes from the border states and the District of Columbia. His only loss there was Oklahoma. Combining the 11-state South and the 6-state Border South and D.C., Carter built a lead of 161 to 20 . His remaining electoral vote support came from eight states worth 136 electoral votes. In this regard, wrote Nicol Rae, Carter "was an aberration in the pattern of Democratic nominees"; he was the "exceptional case." 18

Republicans confessed, "Jimmy Carter was too much to overcome." Despite attempts to portray Carter as a liberal, "Southern-fried [George] McGovern," Bob Dole, the Republican vice-presidential candidate, said Carter made the South "the one area we couldn't crack." That was the difference between winning and losing in $1976 .^{19}$

Twelve years earlier, in 1964, David Potter lamented that the South, by supporting Republican candidate Barry Goldwater in greater proportion than the rest of country, appeared "more at odds with the dominant trends of the nation than at any time since Appomattox, if not before"; it stood "at the nadir of political impotence." In 1976, the South on the back of Carter climbed to the political apex and seemed destined to set the trends for the foreseeable future. ${ }^{20}$

18 This 11-state definition of the South is widely used in U.S. southern political studies. See V.O. Key, Jr., Southern Politics in State and Nation (Knoxville, TN: The University of Tennessee Press, 1984; originally published in 1949). The border states include Delaware, Maryland, West Virginia, Kentucky, Missouri, and Oklahoma. Nicol C. Rae, Southern Democrats (New York: Oxford University Press, 1994), 55-57.

19 B. Drummond Ayres, Jr., "Many Democrats in South Win on Carter's Coattails; GOP Weakened in Region at All Political Levels," New York Times, November 4, 1976, 23; Douglas E. Kneeland, "Dole Says GOP Loss of South Cost It the Presidential Election," New York Times, November 4, 1976, 26. In a strategy manual, the Ford campaign recognized the unique regional challenge Carter presented. It warned supporters not to "attack him personally [in the South] since this would cause a backlash of regional pride." According to another document, a "Constituency Analysis" in "Strategy Details: Section B - Constituency Groups", the campaign additionally knew that waging an ideological fight between conservatism and liberalism would be "more difficult", because Carter was "still perceived as significantly more moderate than [Hubert] Humphrey, [Edward] Kennedy." See “Campaign Strategy for President Ford 1976," Michael Raoul-Duval Papers, Box 13, Folder: Pres. Campaign - Campaign Strategy Program \#3, 111-113, Gerald R. Ford Presidential Library and Museum, Ann Arbor, Michigan.

20 David M. Potter, The South and the Sectional Conflict (Baton Rouge, LA: Louisiana State University, 1968), 32-33. 


\section{"There are a few who think that since I am a southern governor, I must be a secret racist ..."}

After he left the White House, Carter maintained that his southern background may in fact contributed to some of his difficulties while in office. As an example, he believed that a southern stigma contributed to negative news coverage and difficult relations with the national press.

In February 1985, Carter explained to journalism students at Emory University, "There is still suspicion or belief among members of the Washington press leaders that there is something basically wrong with a southerner. They think that we're still inherently racist or have a lower level of intelligence." Possibly, suggested one Atlanta columnist Bill Shipp, "Carter may be a bit too self-conscious about his southernness as well as his presidency to view White House press coverage objectively." "Still," he averred, "the question lingers: Does a southerner as a presidential candidate have a unique handicap?" Implicitly, this writer thought so: "the Carter presidency, seen by much of the American public as inept and faltering, was largely a media creation." Helen Thomas, who served many years as a member of the White House press corps, observed that the southern presidents she covered had a "hang-up" about being regularly misunderstood or disrespected. Whether these presidents felt this way or not, she acknowledged that there might be some truth to such claims in the Northeast. ${ }^{21}$

Carter's post-presidential complaint about regional bias was not said out of bitterness. He confronted it on occasion when he ran for president and during his presidency. In the late spring of 1976, as he was emerging as the Democratic frontrunner for the nomination, Carter was asked in an interview with Bill Moyers to answer a question from a friend of his from New York City. Moyers said, "I ran into a friend who's a lawyer in a large firm in New York, and he said, 'Could I ask you to ask Jimmy Carter something?' And I wrote it down. He said, 'What bothers me about Jimmy Carter, the human being, is that he strikes me as a decent but provincial and narrow-minded man from the South who's lived most of his life in that environment. And I'd like to know how a man like that expects to lead a pluralistic society, not to mention the Western world." Summing up the

21 Debbie Newby, "Reagan has nice touch, Carter says," Atlanta Journal-Constitution, February 21, 1985 , A3; Bill Shipp, "Did Southern roots trip Carter?" Atlanta Journal-Constitution, February 25, 1985, A9; Helen Thomas, Thanks for the Memories, Mr. President: Wit and Wisdom from the Front Row at the White House (New York: Scribner, 2003), 113. 
concerns about Carter, one national columnist asked, "Is America ready for a Christian president from the South?"22

According to a March 1976 Time magazine article, Carter's southern connections and religiosity were enumerated among the main reasons many liberal Democrats were uncertain in backing the former Georgia governor. "One of the motives for the [liberal] attacks on Carter is left unstated-at least publicly. [Carter] is a proud southerner, and that region is still suspect among the northern liberals in the Democratic Party...His southern-style evangelism, showing up in so many of his speeches, irritates the less devout. They are uneasy about a man who uses the word God so easily, so often." On the front cover of the same issue, on his way to the Florida primary, Carter was depicted as a bumpkin riding a donkey while shelling peanuts, wearing a farmer's hat, and sporting a Confederate battle flag tie. ${ }^{23}$

In the 1976 Playboy interview, Carter complained about journalists who still treated the South as a "suspect nation." "There are a few who think that since I am a southern governor, I must be a secret racist or there's something in a closet somewhere that's going to be revealed to show my true colors." ${ }^{4}$

In Keeping Faith, his presidential memoir, Carter noted some of the scorn he encountered. He was frustrated by the efforts to cast the South as uniquely mired in prejudice and backwardness.

"Before we arrived in Washington, some of the society-page writers were deploring the prospective dearth of social grace in the White House and predicting four years of nothing but hillbilly music, and ignorant Bibletoting southerners trying to reimpose Prohibition in the capital city. The local cartoonists had a field day characterizing us as barefoot country hicks with straw sticking out of our ears, clad in overalls, and unfamiliar with the proper use of indoor plumbing. I recall a full-page cartoon depicting an outhouse on the White House lawn, with my mother wearing a sunbonnet and smoking a corncob pipe."

Though he said, "our family was too exuberant to have our spirits damp-

22 Question from Carter, "Interview with Bill Moyers," May 16, 1976, in Conversations with Carter, edited by Don Richardson (Boulder, CO: Lynne Rienner Publishers, 1998), 11; Columnist Joseph Kraft's question was mentioned as part of Cal Thomas' question to Carter. "Question given to Jimmy Carter by Cal Thomas of KPRC-TV News in Houston, Texas,” April 20, 1976, in Wesley Pippert, The Spiritual Journey of Jimmy Carter: In His Own Words (New York, Macmillan Publishing Company, 1978), 117.

23 "Jimmy Carter: Not Just Peanuts," Time, March 8, 1976, 16.

24 Carter, "Interview with Robert Scheer," Playboy, November 1976, 66. 
ened" by such anti-southern caricatures and "regional ridicule," Carter was aware that other presidents from the South believed that non-southerners viewed them with contempt. "I knew that Lyndon Johnson went to his grave convinced that he was a victim of regional prejudice." ${ }^{25}$

\section{"I've proven...the southerners don't have to worry about eventually coming out on top"}

Carter was a proud southerner who believed in the "Southland." Like other "New South" politicians elected in the early 1970s, he was convinced the South, an integrated South, was now prepared to bind "our country back together" and show "the way to pull white and black people together." ${ }^{26} \mathrm{He}$ thought that, with his team of fellow Georgians (e.g., his wife, Rosalynn Carter, his press secretary, Jody Powell, and his chief of staff, Hamilton Jordan) around him, the South had something to teach the United States and even the world not just on matters of race and ethnicity, but across a range of issues. His 1976 election provided possibilities.

In his presidential rhetoric, Carter utilized regionalism to build trust with other Americans and with international actors. He thought his southern identity and his region's experiences could be positively used as president. In some critical ways, he postulated, the American South had more in common with the global South than with the rest of the United States.

At an occasion in Atlanta, Georgia, one year into his presidency, Carter said, "We who have seen the devastation of war and the social and psychological devastation of racial discrimination know the value of harmony, of family, and of a common purpose." During his re-election bid in 1980, he told supporters in Houston, Texas, that he could "take the [southern] heritage that is part of our own consciousness and let it be beneficial for the rest of the country." In New Orleans, he vowed "we're going to keep the hands on the reins in Washington, with southerners who brought our nation together in a unified way and have a better future for us all.,"27

25 Carter, Keeping Faith: Memoirs of a President (Fayetteville, AR: University of Arkansas Press, 1995; originally published in 1982), 24-25; For Johnson's charge of anti-southern bias in the country, see Lyndon Johnson, The Vantage Point: Perspectives of the Presidency, 1963-1969 (New York: Holt, Rinehart and Winston, 1971), 95-96.

26 Carter, "Remarks at a Fundraising Reception and Dinner for Charles Ravenel in Columbia, South Carolina," September 22, 1978, Public Papers of the Presidents, Book II, 1585.

27 Carter, "Remarks at the Southern Salute to the President Dinner in Atlanta, Georgia," January 20, 1978, 
Before a Polish-American audience in Illinois, he shared with his listeners his "disgust" with Polish jokes because "as a southerner" he knew "what it means to be the butt of jokes." Such ethnic jokes and derisive comments, Carter continued, are "especially revolting among great and proud people." "As an American and a southerner," he resented "such slander." Before an Italian American audience, he noted that Italian Americans were still "punished unfairly by cruel stereotypes." He empathized with them. He explained that "as a southerner, as a Georgian," he, too, "had been stigmatized because of the region of my birth. ${ }^{28}$

During his 1977 visit to Poland, Carter said he could identify with the historic suffering of the Polish people because the South had been defeated and devastated in war. "Georgia's capital of Atlanta was completely destroyed in war, as was the city of Warsaw. But although we [southerners] have suffered greatly, no other nation has borne such suffering as Poland." With the first foreign leader to visit the Carter White House, Mexican President Jose Portillo, he noted that one of things Mexicans and southerners shared was historical interference from Washington. "The Mexican people know what Yankee imperialism means, and being from Georgia-I have also heard the same phrase used." 29

With Nigeria's president Olusegun Obasanjo and Liberia's president William Tolbert, he identified with their countries' efforts to recover from civil war. "Those of us who live in either the North or South in our own country know that it took us a hundred years to overcome the consequences of a divisive civil war in our own country." 30

Public Papers of the Presidents, Book I, 157; "Remarks at a Rally in Houston, Texas," October 31, 1980, Public Papers of the Presidents, Book III, 2604; "Remarks at a Rally in New Orleans, Louisiana," October 21, 1980, Public Papers of the Presidents, Book III, 2402.

28 Carter, "Remarks at the $100^{\text {th }}$ Anniversary Dinner of the Polish National Alliance in Niles, Illinois," September 20, 1980, Public Papers of the Presidents, Book II, 1853-1854; "Remarks at the National ItalianAmerican Foundation's Third Biennial Tribute Dinner," September 13, 1980, Public Papers of the Presidents, Book II, 1720.

29 Carter, "Remarks at a Toast with Polish First Secretary Edward Gierek in Warsaw, Poland," December 30, 1977, Public Papers of the Presidents, Book II, 2215; "Remarks at a Toast with Mexican President Jose Lopez Portillo," February 14, 1977, Public Papers of the Presidents, Book I, 152.

30 Carter, "Remarks at a Toast with Nigerian President Olusegun Obasanjo," October 11, 1977, Public Papers of the Presidents, Book II, 1772; "Remarks at a Toast with Nigerian President Olusegun Obasanjo in Lagos, Nigeria," April 2, 1978, Public Papers of the Presidents, Book I, 660; "Remarks at a Working Luncheon with Liberian President William Tolbert in Monrovia, Liberia," April 3, 1978, Public Papers of the Presidents, Book I, 676-677. 
In an address at the United Nations, Carter said he sympathized "with leaders of the developing nations" because "I come from a part of the United States which is largely agrarian and which for many years did not have the advantages of adequate transportation or capital or management skills or education which were available in the industrial states of our country." He made similar remarks before the Venezuela's Congress in 1978. Because of the recent transformation in the South, he said, "I can understand the unfulfilled yearnings of other people in developing nations to share these blessings of life." Then, in Nigeria, he said, "I know something about social change. In my own lifetime, I've seen the region of my birth, the southern part of the United States, changed from a place of poverty and despair and racial division to a land of bright promise and opportunity and increasing racial harmony." 31

In a speech before the World Health Assembly, he informed the audience that he understood the ongoing devastating effects of diseases in the developing world because "my home state of Georgia" had similarly suffered and "some areas of the southeastern United States" continued to suffer. To U.S. officials at the United Nations, he said his administration could give "southerners" around the world hope that they too can succeed and close the North-South gap because the American South had done so. "I think as we deal with the North-South question, which is one of the most difficult of all, it's accurate to say that we've had similar struggle within the United States, too. And perhaps I've proven that if you struggle long enough, the southerners don't have to worry about eventually coming out on top." With himself as president and Andrew Young at the United Nations as ambassador, two Georgians, global South countries might look to the Carter administration as one that "understands their problem," "speaks their language," and will listen as "they put forward their woes and their hopes for the future." 32

31 Carter, "Address Before the United Nations General Assembly," March 17, 1977, Public Papers of the Presidents, Book I, 448; "Remarks Before the Venezuelan Congress in Caracas," March 29, 1978, Public Papers of the Presidents, Book I, 623; "Remarks at the National Arts Theatre in Lagos, Nigeria," April 1, 1978, Public Papers of the Presidents, Book I, 650.

32 Carter, "Message to the Thirtieth World Health Assembly in Geneva, Switzerland," May 5, 1977, Public Papers of the Presidents, Book I, 839; "Remarks to Members of the U.S. Delegation and U.S. Officials of the United Nations," October 4, 1977, Public Papers of the Presidents, Book II, 1726; "The President's News Conference," June 13, 1977, Public Papers of the Presidents, Book I, 1108. 


\section{"... To save our country and its freedom, the South is always in the front"}

According to Joseph Fry, Carter took foreign policy stances that were in sharp contrast to the predominant southern view. In Dixie Looks Abroad, Fry argued that "most southerners and their representatives in Congress" preferred "a unilateral emphasis" and "a nationalistic policy" in international relations. They were "staunchly anticommunist" and largely hostile "toward the United Nations, immigration, and foreign aid," and "were consistently more pessimistic than other Americans about the long-term prospects for international peace." Moreover, the South, Fry continued, long looked to "military solutions" for international problems and exhibited "little patience for constraints on U.S. power and limited war." Fry concluded that Carter ultimately "adopted policies in conflict" with these general southern preferences. ${ }^{33}$

Carter did not disagree. But he was not about to concede the point. He offered his own understanding of what is southern. He recognized the martial proclivities of his native region and readily acknowledged in his speeches the South's tradition of military honor and sacrifice. For southerners, he said, commitment to the military and a strong defense was "a matter of heritage." Quoting the first American president, the first southern president, Carter said George Washington "warned us bluntly" how to preserve the peace and security of the country: "To be prepared for war is one of the most effectual means of preserving peace." Elsewhere, he boldly asserted that if he did not support a strong military "I wouldn't be a true southerner." ${ }^{34}$

At the 1977 Veterans Day ceremonies at Arlington National Cemetery, Carter explained why southerners held these views. He said, "I come from the South" and "We [in the South] are one of the parts of the nation who have suffered severely, along with those who fought in the War Between the States." ${ }^{35}$ In 1978, in Winston-Salem, North Carolina, he said, "Southern-

33 Joseph A. Fry, Dixie Looks Abroad: The South and U.S. Foreign Relations, 1789-1973 (Baton Rouge, LA: Louisiana State University Press, 2002), 223, 233, 262, 296.

34 Carter, "Interview with Jack Bass and Walter De Vries," 1974, partial transcript available at Documenting the American South, http://docsouth.unc.edu/sohp/A-066/A-066.html; "Remarks at Veterans Day Ceremonies at Arlington National Cemetery," November 11, 1978, Public Papers of the Presidents, Book II, 2013; "Remarks at Rally in Tuscumbia, Alabama," September 1, 1980, Public Papers of the Presidents, Book II, 1603. He noted again his "Deep South" background as a reason for his commitment to a strong military defense during a question-and-answer session at the "Carter Presidency \& Lessons for the $21^{\text {st }}$ Century Conference," University of Georgia, Athens, Georgia, January 20, 2007.

35 Carter, "Remarks at Veterans Day Ceremonies at Arlington National Ceremony, Virginia," October 24, 1977, Public Papers of the Presidents, Book II, 1901. 
ers, whose ancestors a hundred years ago knew the horrors of a homeland devastated by war, are particularly determined that war shall never come to us again." In Savannah, Georgia, Carter made the same point. "The South," he said, "has known better than any other part of our great nation what it means to be devastated and occupied as a result of war." ${ }^{36}$ On the campaign trail in September 1980, in Startex, South Carolina, he proclaimed,

"The Southland has always been in the forefront of patriotism, courage, and dedication. When you look down the list of those honored for heroism, the South is at the top. When you look at the list of those who gave their lives in action to save our country and its freedom, the South is always in the front." ${ }^{37}$

\section{The following month in Columbia, South Carolina, Carter explained,}

"The South's been always interested in a strong defense - always. Whenever our nation's been tested in war, the battleground casualty figures and those lost in prison camps have always shown that the South came forward, quick, patriotically, and first. But at the same time we know the value of peace. No part of the nation has suffered so much from the ravages of war as Georgia and South Carolina." 38

In Memphis, Tennessee, he remarked, "A commitment to strong defense has been a habit of southerners, who've always been the first ones to volunteer, have been willing to lay down their lives for the defense of our country." 39

To counter the impression that he was weak on national defense, Carter explained to reporters of the Detroit Free Press, "I'm a professional military officer - that's my training - and I'm also from the South, where strong defense is a major commitment of almost any person who runs for public office." As far away as Seattle, Washington, he tried to reassure voters that he could be trusted with national defense because of his regional credential. "We believe also in a strong defense. I'm a southerner." ${ }^{40}$ Because the South

36 Carter, "Address at Wake Forest University in Winston-Salem, North Carolina," March 17, 1978, Public Papers of the Presidents, Book II, 535; "Remarks at the Hibernian Society Dinner in Savannah, Georgia," March 17, 1978, Public Papers of the Presidents, Book I, 542.

37 Carter, "Remarks to Employees of Startex Mills in Startex, South Carolina," September 16, 1980, Public Papers of the Presidents, Book II, 1760.

38 Carter, "Remarks at a Meeting with State and Local Democratic Leaders in Columbia, South Carolina," October 31, 1980, Public Papers of the Presidents, Book III, 2576.

39 Carter, "Remarks and Question-and-Answer Session at a Town Meeting in Memphis, Tennessee," October 31, 1980, Public Papers of the Presidents, Book III, 2597.

40 Carter, "Interview with Joe Stroud and Remer Tyson of the Detroit Free Press in Flint, Michigan," October 1, 1980, Public Papers of the Presidents, Book III, 2011; "Remarks at a Rally in Seattle, Washington," 
has known war, total war, Carter said to supporters in Lakeland, Florida, southerners, especially southerners, know that "only through strength can we keep our Nation at peace." In Atlanta, he said southerners have "always been highly patriotic, maybe because our families, our ancestors remember the devastation of the War Between the States, when Atlanta itself was destroyed." At another time, he said many southerners "are descended from people who know what it means to go through a terrible war and to live under occupation and to struggle to restore what we've lost." ${ }^{\text {"1 }}$

\section{"...Because we understand the cost of war, we also believe in the nobil- ity of peace"}

According to Carter, the South had an informative, useful past, and a proper reading of it could be instructive for the present. It was not a "lost cause". Rather, as president, he aimed to apply lessons of war and defeat and the South's long struggle with racial-ethnic conflict constructively and correctly in the modern world. He further aimed to apply principles of his Christian faith. The Middle East, namely the Arab-Israeli conflict, provided a chance.

Because of energy dependence, Carter understood the economic importance of the Middle East. He also acknowledged that conflict there could trigger a superpower war between the United States and the Soviet Union. He knew that Israel had political importance, specifically for the American Jewish community, a community with strong ties to the Democratic Party. But the turbulent region was also personally important for Carter.

Carter saw the Middle East through a religious and regional perspective. Like other evangelicals, the region was sacred space; it was "the Holy Land," "the land of the Bible," and the birthplace of the three great religions of Judaism, Christianity, and Islam. Peace in the region was envisioned in the Bible. He believed that the pursuit of peace reflected the teachings of Jesus. Because of this, peace between Israel and the Arab world was a constant "on my agenda, and on my mind." 42

Moreover, Carter viewed the conflict between Arab and Jew, Egyptian,

November 3, 1980, Public Papers of the Presidents, Book III, 2680.

41 Carter, "Remarks at a Rally in Lakeland, Florida," October 31, 1980, Public Papers of the Presidents, Book III, 2582; "Remarks at the Southern Salute to the President Dinner in Atlanta, Georgia," January 20, 1978,

Public Papers of the Presidents, Book I, 156-157; "Remarks at a Fundraising Reception and Dinner for Charles Ravenel in Columbia, South Carolina," September 22, 1978, Public Papers of the Presidents, Book II, 1582 .

42 Carter, Keeping Faith, 280-281. 
Palestinian and Israeli as internecine, fraternal strife. It was a conflict akin to that in much of southern history. He likened the conflict to the troubled history between white and black southerners. ${ }^{43}$

"We have a lot in common, a belief in one another. We share a common faith in Christ. We speak the same language. We sing the same hymns. We've seen the same poverty and the same disease. We've seen the same struggles in the South and the same growth. We've overcome the same obstacles. It has bound us together in the spirit of brotherhood and love." ${ }^{44}$

In his judgment, the root of the problem was the same: racism and feelings of superiority. Once these sources of the conflict were arrested, racial reconciliation, regional healing could commence. This is the new South and it could be the new Middle East.

One of the most poignant examples of Carter's use of southern history involved a trip to Gettysburg in September 1978. When negotiations between Egyptian President Anwar Sadat and Israeli Prime Minister Menachem Begin were breaking apart at the Camp David presidential retreat, Carter, in the role of mediator, took them on an excursion to one of the bloodiest Civil War battlefields. ${ }^{45}$

In his first speech of the 1980 fall re-election campaign, with key regional leaders at his side, including Governor Wallace and Al Gore, Carter spoke of the South - Middle East connection. Carter argued that the vanquished Confederacy made the South a real, worldly place because its story did not fit the American narrative of exceptional progress, triumph, and innocence. For this, he explained, "The role of peacemaker comes right out of our own history and our own heritage." He then proceeded to talk about an important moment during the thirteen-day Camp David summit. ${ }^{46}$

Carter revealed at the Alabama rally that when "there was a deadlock" in the negotiations and "we weren't getting anywhere," he decided to take Sadat and Begin to the 1863 Pennsylvania battle site. After attending a worship service at Camp David on Sunday, September 10, Carter escorted the Middle East leaders to nearby Gettysburg National Military Park. They

43 See William B. Quandt, Camp David: Peacemaking and Politics (Washington, DC: The Brookings Institution, 1986), 31; See also Carter, Sources of Strength: Meditations on Scripture for a Living Faith (New York: Three Rivers Press, 1997), 74, 98.

44 Robert W. Turner, "I'll Never Lie to You": Jimmy Carter in His Own Words (New York: Ballantine Books, 1976), 20.

45 Carter, Sharing Good Times (New York: Simon and Schuster, 2004), 78.

46 Carter, "Remarks at Rally in Tuscumbia, Alabama," September 1, 1980, Public Papers of the Presidents, Book II, 1604 
spent two hours there. ${ }^{47}$ "I wanted to show these two men that we Americans know something about war, and we know about neighbors fighting against neighbors," Carter noted, "Cemetery Hill, Seminary Ridge, Little Round Top, Devil's Den," places "where more than 40,000 young Americans," Union and Confederate, "fell in battle." They visited the Virginia Memorial, atop of which is an equestrian statue of Confederate general Robert E. Lee, the site of where President Abraham Lincoln delivered the Gettysburg Address, and the High Water Mark of the Rebellion Memorial. Carter said he reflected on this at the battleground,

"I remembered that in all our nation's wars, every war, young men from the South have led the rolls of volunteers and also led the rolls of casualties. We southerners believe in the nobility of courage on the battlefield, and because we understand the cost of war, we also believe in the nobility of peace."

"After that day at Gettysburg," Carter concluded, "we went back to Camp David, and you know the rest. We hammered out a peace agreement between Egypt and Israel." ${ }^{48}$

Press secretary Powell reaffirmed Carter's point. "The Civil War (or War Between the States, if your family was on the right side) provides for southerners a perspective that differs from most Americans." "Tales of glory and valor," he stated, "are forever entwined with bitter memories of defeat, humiliation, and terrible loss. In the South, one fourth of all white males of military age were killed or wounded in less than four years." Carter, he said, knew this. "The South of the President's childhood" to his presidency was a South whose suffering "in substance and spirit from that loss" was still extant, "recovery was not yet complete." "As a southerner and as a President," Gettysburg was a reminder that presidents are commanders in chief endowed "with the power to send men to fight and die." As a southerner and as a president, "Carter understood, in a way that another president might not, the experience of Arab and Israeli," and that war is often "a result of the failure of politics and the shortsightedness of politicians." Perhaps, Powell pondered, the battlefield visit was more beneficial to Carter than his two guests. It provided him an opportunity to tell about the South's history, to share "what he understood about war and the consequences of failure." 49

47 See diary entry for September 10, 1978, "The Jimmy Carter Presidential Daily Diary Online," Jimmy Carter Library and Museum, https://www.jimmycarterlibrary.gov/assets/documents/ diary/1978/.

48 Carter, "Remarks at Rally in Tuscumbia, Alabama," September 1, 1980, Public Papers of the Presidents, Book II, 1604.

49 Jody Powell, The Other Side of the Story (New York: William Morrow and Company, 1984), 76-77. 


\section{"...You have a sensitivity about our problems...because you're from the South"}

Carter impressed his international visitors at Gettysburg. Israeli Foreign Minister Moshe Dayan especially enjoyed "the descriptions, stories and comments by President Carter." ${ }^{50}$ Though the Israelis had studied the events and battles of the war, Dayan explained that Carter made Gettysburg memorable and come to life. "We were, of course, accompanied by a professional guide; but Carter, a southerner from Georgia, could not contain his feelings as the guide made his dry recital, and he injected his own observations on the moves of the rival Federal and Confederate troops." He spoke, Dayan observed, "with great emotion" and "with genuine warmth and praise for General Lee and his men." Impressed with the presentation, he said Carter "seemed to know every hill and boulder which had served them as cover."

From Dayan's account, Carter mostly described the events from a southern perspective. He said, Carter "told the story of how the tattered, bedraggled and barefoot southern fighters had an additional incentive to capture Gettysburg upon hearing that it had large stores of boots." He spoke as if he was "talking about his own family." The Israeli Foreign Minister said the President described the efforts of the defeated Confederate forces "with pride."

Alongside his Christian beliefs, Anwar Sadat confided to Carter that he believed that his southern heritage influenced and prepared him well for taking the lead for Middle East peace. Based on Carter's recollection, this is what Sadat said to him at Camp David:

"I believe that you have a sensitivity about our problems in the Middle East because you're from the South, because the South is the only part of the United States and southerners are the only people in the United States that really know what it means to suffer the tortures of the aftermath of a war in an occupation government and deprivation for a while and a struggle for the overcoming of prejudice and hatred between one race and another." 51

50 Moshe Dayan, Breakthrough: A Personal Account of the Egypt-Israel Peace Negotiations (New York: Random House, 1981), 170-171.

51 Carter, "Remarks at a Fundraising Reception and Dinner for Charles Ravenel in Columbia, South Carolina," September 22, 1978, Public Papers of the Presidents, Book II, 1585; "Remarks at the $30^{\text {th }}$ Annual Brotherhood Citation Dinner of the National Conference of Christians and Jews," May 29, 1979, Public Papers of the Presidents, Book I, 969; see also Keeping Faith, 398. 
Though atypical for most Americans, Sadat reasoned that the more worldly experiences of the South provided Carter "not only a special insight but perhaps an additional commitment to bring a resolution between two people that have long hated each other." The Egyptian President sensed Carter's southern mind. He apprehended that both white and black southerners knew suffering and loss, and had a historical rendezvous with tragedy, defeat, and subjugation. This, Carter's southern perspective and historical consciousness, Sadat posited, was crucial to the diplomatic success. ${ }^{52}$

\section{"To new heights of achievement and common purpose"}

In his book What Caused the Civil War?, Edward Ayers explained that southern history may not provide southerners any "special wisdom from its experience of defeat" for they became "more bellicose and jingoistic" in foreign policy than most other Americans. ${ }^{53}$ Jimmy Carter offered an alternative.

Region mattered. Carter was not merely a president from the South, but a southern president. In several instances, regionalism informed his presidential rhetoric, influenced his presidential priorities, and inspired his presidential behavior. It was Carter's hope and expectation that his presidency would not only heal the country from the effects of Watergate and Vietnam, but also heal the sectional division and emotional wounds still lingering since the 1860 s.

Despite an anti-southern bias that occasionally undercut his presidency, he claimed being a southern president was beneficial. Beside his religious faith, being southern provided him an understanding of and empathy toward other peoples who were still going through the southern-type experiences of underdevelopment, disease, poverty, racial-ethnic animosity, and war. Because the South changed and made comprehensive improvements, there was hope for others. In this way, the South had a useable past. Like the South, peoples in the global South may rise again, rising "to new heights

52 Carter, "Remarks at a Fundraising Reception and Dinner for Charles Ravenel in Columbia, South Carolina," September 22, 1978, Public Papers of the Presidents, Book II, 1585.

53 Edward L. Ayers, What Caused the Civil War?: Reflections on the South and Southern History (New York: W.W. Norton and Company, 2005), 186-187. 
of achievement and common purpose."54 The southern experience may have even prepared him to be a peacemaker. At least, he thought so. In the Middle East, the southern president ably pursued a historic peace accord with Egypt and Israel. Arguably, his post-presidential work with the Carter Center may have demonstrated the utility of his regional sensibilities even more clearly. 